\title{
Gambaran Kejadian Ketuban Pecah Dini (KPD) di RSUP Prof. Dr. R.D. Kandou Manado Tahun 2018
}

\author{
Teuku I. Syarwani, ${ }^{1}$ Hermie M. M. Tendean, ${ }^{2}$ John J. E. Wantania ${ }^{2}$
}

\author{
${ }^{1}$ Program Studi Pendidikan Dokter Fakultas KedokteranUniversitas Sam Ratulangi Manado \\ ${ }^{2}$ Bagian Kebidanan dan Kandungan Fakultas Kedokteran Universitas Sam Ratulangi \\ Manado \\ Email: ikhsanappmc828@gmail.com
}

\begin{abstract}
Premature rupture of membrane (PROM) is the rupture of the membrane before delivery. This study was aimed to determine the profile of PROM based on maternal age, parity, occupation, duration of PROM, type of delivery, gestational age, and perinatal outcomes. This was a descriptive and retrospective study. Samples were delivery women who had PROM at gestational age $\geq 37$ weeks and $<37$ weeks at Prof. Dr. R. D. Kandou Manado form January 1 to December 31, 2018. The results showed a total of 78 patients of PROM. Most patients were 2034 years $(65.39 \%)$, senior high school educated $(71.80 \%)$, housewifery $(69.23 \%)$, multiparity (58.87\%), PROM $\geq 24$ hours (65.38\%), gestational age $\geq 37$ weeks $(85.90 \%)$, cesarean delivery (85.90\%), and Apgar score of 7-10 (79.48\%). In conclusion, PROM patients in 2018 were more common in age 20-34 years, senior high school educated, housewifery, multiparity, PROM $\geq 24$ hours, gestational age $\geq 37$ weeks, cesarean delivery, and a perinatal outcome of Apgar score of 7-10 (79.48\%)
\end{abstract}

Keywords: premature rupture of membrane

\begin{abstract}
Abstrak: Ketuban pecah dini (KPD) adalah keadaan pecahnya selaput ketuban sebelum persalinan. Penelitian ini bertujuan untuk mengetahui gambaran kejadian KPD berdasarkan usia ibu, paritas, pekerjaan, lamanya ketuban pecah, jenis persalinan, usia kehamilan, dan luaran perinatal. Jenis penelitian ialah deskriptif retrospektif. Sampelpenelitian ini ialah ibu bersalin yang mengalami KPD pada usia kehamilan $\geq 37$ minggu dan $<7$ minggu di RSUP Prof. Dr. R. D. Kandou Manado periode 1 Januari -31 Desember 2018. Hasil penelitian mendapatkan total 78 kasus KPD yang terdiri dari ibu berusia $20-34$ tahun $(65,39 \%)$, pendidikan SMA $(71,80 \%)$, IRT $(69,23 \%)$, multipara $(58,87 \%)$, ketuban pecah $\geq 24$ jam $(65,38 \%)$, usia kehamilan $\geq 37$ minggu $(85,90 \%)$, persalinan seksio sesarea $(85,90 \%)$, dan Apgar score 7-10 (79,48\%). Simpulan penelitian ini ialah kasus KPD pada tahun 2018 yang paling sering pada usia ibu 2034 tahun, pendidikan SMA, IRT, multipara, ketuban pecah $\geq 24$ jam, usia kehamilan $\geq 37$ minggu, persalinan seksio sesarea, dan luaran perinatal Apgar score 7-10.
\end{abstract}

Kata kunci: ketuban pecah dini

\section{PENDAHULUAN}

Ketuban pecah dini (KPD) atau sering disebut premature rupture of the membrane (PROM) adalah keadaan pecahnya selaput ketuban sebelum persalinan. Bila KPD terjadi sebelum usia kehamilan 37 minggu disebut ketuban pecah dini dalam kehamilan prematur. Insidensi KPD berkisar antara $8-10 \%$ dari semua kehamilan. Pada kehamilan aterm insidensinya bervariasi antara 6-19 \% sedangkan pada kehamilan preterm insidensinya $2 \%$ dari semua kehamilan. ${ }^{1}$

Kejadian KPD di Amerika Serikat terjadi pada 120.000 kehamilan per tahun dan berkaitan dengan risiko tinggi terhadap kesehatan dan keselamatan ibu, janin, dan neonatal. Sebagian besar ketuban pecah dini 
pada kehamilan preterm akan lahir sebelum aterm atau persalinan akan terjadi dalam satu minggu setelah selaput ketuban pecah. Sekitar $85 \%$ morbiditas dan mortalitas perinatal disebabkan oleh prematuritas. Ketuban pecah dini merupakan salah satu penyebab prematuritas dengan insidensi 30-40\%. ${ }^{1}$ Menurut data dari Kementerian Kesehatan Republik Indonesia, angka kematian ibu dan neonatus di Indonesia pada tahun 2015 masing-masing ialah 305 per 100.000 kelahiran hidup dan 32 per 1.000 kelahiran hidup. ${ }^{2}$ Salah satu penyebab mortalitas ibu dan neonatus adalah kejadian ketuban pecah dini. Hingga saat ini belum ada data yang dapat menunjukkan secara pasti angka kejadian KPD secara nasional.

Dalam suatu penelitian yang dilakukan di RSUP Prof. Dr. R. D. Kandou Manado dilaporkan bahwa dari 3.810 persalinan di rumah sakit tersebut terdapat $1,54 \%$ atau 59 kasus KPD. Sebanyak $72 \%$ kasus KPD terjadi pada usia kehamilan lebih dari 37 minggu, dengan sebagian besar ibu berada pada rentang usia 20-24 tahun. ${ }^{3}$ Sehubungan dengan hal ini, maka diharapkan pengetahuan tentang kondisi-kondisi yang memengaruhi keselamatan dan kesehatan kehamilan dapat dipahami oleh masyarakat, terutama ibu hamil. Dengan demikian dapat menjadi pegangan dalam pencegahan atau preventif dalam rangka menurunkan angka KPD sehingga komplikasi yang tidak diinginkan pada ibu dan janin dapat dihindari.

Berdasarkan uraian ini, penulis tertarik ingin melakukan penelitian mengenai gambaran kejadian KPD di RSUP Prof. Dr. R.D. Kandou pada tahun 2018.

\section{METODE PENELITIAN}

Penelitian ini dilakukan di Bagian Obstetri dan Ginekologi di RSUP Prof. Dr. R. D. Kandou Manadopada bulan September 2019-November 2019. Jenis penelitian ini ialah deskriptif retrospektif.

Populasi penelitian ini ialah seluruh ibu bersalin di RSUP Prof. Dr. R. D. Kandou periode 1 Januari-31 Desember 2018. Sampel penelitian ini ialah ibu bersalin yang mengalami KPD pada usia kehamilan <37 minggu dan $\geq 37$ minggu di RSUP Prof. Dr. R.D. Kandou periode 1 Januari-31 Desember 2018. Variabel penelitian ini terdiri dari usia ibu, pendidikan, pekerjaan, paritas, lamanya ketuban pecah, usia kehamilan, jenis persalinan, dan luaran perinatal.

Penelitian ini telah mendapat persetujuan dari Komisi Etik Penelitian Kesehatan RSUP Prof. Dr. R. D. Kandou Manado, dengan nomor keterangan layak etik yaitu No. 056/EC/KEPK-KANDOU/X/2019.

\section{HASIL PENELITIAN}

Selama periode 1 Januari-31 Desember tahun 2018 di Bagian Obstetri dan Ginekologi Fakultas Kedokteran Universitas Sam Ratulangi/RSUP Prof. Dr. R. D. Kandou Manado, didapatkan 78 kasus KPD. Berdasarkan usia ibu, frekuensi terbanyak pada ibu berusia 20-34 tahun yaitu 51 kasus $(65,39 \%)$. Berdasarkan pendidikan, frekuensi terbanyak pada SMA $(71,80 \%)$. Berdasarkan pekerjaan, frekuensi terbanyak pada IRT $(69,23 \%)$. Berdasarkan paritas, frekuensi terbanyak pada ibu dengan multipara $(58,87 \%)$, Berdasarkan lamanya ketuban pecah, frekuensi terbanyak pada ketuban pecah $>24$ jam $(65,38 \%)$. Berdasarkan usia kehamilan, frekuensi terbanyak pada $\geq 37$ minggu $(85,90 \%)$. Berdasarkan jenis persalinan, frekuensi terbanyak pada persalinan seksio sesarea $(85,90 \%)$. Berdasarkan luaran perinatal, Apgar score 7-10 merupakan yang terbanyak $(79,48 \%)$

Tabel 1 memperlihatkan distribusi kasus KPD terbanyak pada golongan usia 2034 tahun yaitu 51 kasus $(65,39 \%)$, pendidikan SMA yaitu 56 kasus $(71,80 \%)$, dan pekerjaan ibu rumah tangga (IRT) yaitu 54 kasus $(69,23 \%)$. Tabel 2 memperlihatkan dari 78 kasus KPD, paritas terbanyak yaitu multipara sebanyak 46 kasus $(58,87 \%)$. Tabel 3 memperlihatkan dari 78 kasus KPD, waktu antara lamanya ketuban pecah sampai pasien dirawat terbanyak sesudah 24 jam yaitu 51 kasus $(65,38 \%)$. Tabel 4 memperlihatkan dari 78 kasus KPD, usia kehamilan yang tertinggi yaitu $\geq 37$ minggu sebanyak 67 kasus $(85,90 \%)$. Tabel 5 memperlihatkan dari 78 kasus KPD, jenis persalinan yang sering dilakukan yaitu seksio sesarea 
sebanyak 67 kasus (85,90\%). Tabel 6 mengalami kejadian KPD yaitu 7-10 memperlihatkan dari 78 kasus KPD, nilai sebanyak 62 kasus $(79,48 \%)$. apgar score terbanyak pada bayi yang

Tabel 1. Distribusi kasus KPD berdasarkan usia, pendidikan, dan pekerjaan ibu di RSUP Prof. Dr. R. D. Kandou Manado tahun 2018

\begin{tabular}{lcc}
\hline Karakteristik & Jumlah & \% \\
\hline Usia & & \\
$<20$ tahun & 8 & 10,25 \\
20-34 tahun & 51 & 65,39 \\
$\geq 35$ tahun & 19 & 24,36 \\
Pendidikan & & \\
SD & 3 & 3,84 \\
SMP & 13 & 16,67 \\
SMA & 56 & 71,8 \\
Akademik/PT & 6 & 7,69 \\
Pekerjaan & & \\
Mahasiwa & 6 & 7,69 \\
PNS & 3 & 3,84 \\
Swasta & 15 & 19.24 \\
IRT & 54 & 69,23 \\
Total & 78 & 100 \\
\hline
\end{tabular}

Tabel 2. Distribusi kasus KPD berdasarkan paritas di RSUP Prof. Dr. R. D. Kandou Manado tahun 2018

\begin{tabular}{ccccc}
\hline Jumlah paritas & \multicolumn{2}{c}{ Pervaginam } & \multicolumn{2}{c}{ Seksio sesarea } \\
\hline & $\mathbf{N}$ & $\mathbf{\%}$ & $\mathbf{N}$ & $\mathbf{\%}$ \\
1 & 3 & 3,85 & 22 & 28,21 \\
$2-4$ & 8 & 10,2 & 38 & 48,72 \\
$\geq 5$ & 0 & 50 & 7 & 8,97 \\
Total & 11 & 14,1 & 67 & 85,90 \\
\hline
\end{tabular}

Tabel 3. Distribusi kasus KPD berdasarkan lamanya ketuban pecah di RSUP Prof. Dr. R. D. Kandou Manado tahun 2018

\begin{tabular}{ccccc}
\hline Waktu (jam) & \multicolumn{2}{c}{ Pervaginam } & \multicolumn{2}{c}{ Seksio sesarea } \\
\hline & $\mathbf{N}$ & $\mathbf{\%}$ & $\mathbf{N}$ & $\mathbf{\%}$ \\
$<6$ & 7 & 8,98 & 5 & 6,41 \\
$6-12$ & 2 & 2,56 & 6 & 7,69 \\
$12-24$ & 0 & 0 & 7 & 8,97 \\
$>24$ & 2 & 2,56 & 49 & 62,83 \\
Total & 11 & 14,10 & 67 & 85,90 \\
\hline
\end{tabular}

Tabel 4. Distribusi kasus KPD berdasarkan usia kehamilan di RSUP Prof. Dr. R. D. Kandou Manado tahun 2018

\begin{tabular}{ccc}
\hline $\begin{array}{c}\text { Usia } \\
\text { kehamilan }\end{array}$ & Jumlah & \% \\
\hline$<37$ minggu & 11 & 14,10 \\
$\geq 37$ minggu & 67 & 85,90 \\
Total & 78 & 100 \\
\hline
\end{tabular}


Tabel 5. Distribusi kasus KPD berdasarkan jenis persalinan di RSUP Prof. Dr. R. D. Kandou Manado tahun 2018

\begin{tabular}{ccccc}
\hline $\begin{array}{c}\text { Usia } \\
\text { kehamilan }\end{array}$ & \multicolumn{2}{c}{ Pervaginam } & \multicolumn{2}{c}{ Seksio sesarea } \\
\hline & $\mathbf{N}$ & $\mathbf{\%}$ & $\mathbf{N}$ & $\mathbf{\%}$ \\
$<37$ & 3 & 3,84 & 8 & 10,26 \\
$\geq 37$ & 8 & 10,26 & 59 & 75,64 \\
Total & 11 & 14,10 & 67 & 85,90 \\
\hline
\end{tabular}

Tabel 6. Luaran perinatal pada kasus KPD di RSUP Prof. Dr. R. D. Kandou Manado tahun 2018

\begin{tabular}{ccccc}
\hline $\begin{array}{c}\text { APGAR } \\
\text { score }\end{array}$ & \multicolumn{2}{c}{ Pervaginam } & \multicolumn{2}{c}{$\begin{array}{c}\text { Seksio } \\
\text { sesarea }\end{array}$} \\
\hline & $\mathbf{N}$ & $\mathbf{\%}$ & $\mathbf{N}$ & $\mathbf{\%}$ \\
0 & - & - & - & - \\
$1-3$ & - & - & - & - \\
$4-6$ & 1 & 1,28 & 15 & 19,23 \\
$7-10$ & 10 & 12,82 & 52 & 66,67 \\
Total & 11 & 14,10 & 67 & 85,90 \\
\hline
\end{tabular}

\section{BAHASAN}

Distribusi kasus KPD terhadap usia ibu memperlihatkan bahwa mayoritas ibu berada pada masa usia reproduksi sehat yaitu 20-35 tahun. Hasil penelitian ini sejalan dengan penelitian yang dilakukan oleh Lowing et $\mathrm{al}^{3}$ yang menyatakan bahwa kasus KPD terbanyak berada pada ibu dengan usia 20-24 tahun. Hasil penelitian ini didukung juga oleh penelitian yang dilakukan Emechebe et $\mathrm{al}^{4}$ yang menyatakan bahwa KPD banyak terjadi pada ibu dengan usia produktif.

Distribusi kasus KPD terhadap pendidikan mendapatkan sebagian besar ibu hamil berada pada jenjang pendidikan SMA. Hasil ini sesuai dengan penelitian yang dilakukan oleh Tjahjani $^{5}$ di RB Melati Manukan Surabaya yang mendapatkan mayoritas ibu yang mengalamiKPD berpendidikan menengah (SMA) sebanyak 60 orang $(64,52 \%)$. Umumnya, ibu dengan pendidikan rendah kurang memiliki pengetahuan akan perawatan kehamilannya, baik dari segi nutrisi, aktifitas, personal higiene, kontrol kehamilan pada tenaga kesehatan, faktor-faktor risiko kehamilan, serta tindakan pertama yang dilakukan sehubungan dengan tanda-tanda bahaya kehamilan maupun persalinan. Semakin tinggi pendidikan seseorang semakin mudah menerima informasi sehingga makin banyak pula pengetahuan yang dimiliki. Sebaliknya pendidikan yang kurang akan menghambat perkembangan sikap seseorang terhadap nilai-nilai yang baru diperkenalkan.

Distribusi kasus KPD terhadap pekerjaan mendapatkan mayoritas pekerjaan ibu ialah ibu rumah tangga (IRT). Hasil ini selaras dengan penelitian yang dilakukan oleh Lowing et $\mathrm{al}^{3}$ yang menyatakan bahwa kasus KPD terbanyak pada ibu hamil dengan pekerjaan sebagai IRT yaitu 48 kasus $(1,26 \%)$. Pada dasarnya, aktivitas ibu bersalin yang bekerja dan tidak bekerja tidak akan memengaruhi kesehatan selama ibu masih dapat mengontrol istirahat dan mengetahui batasan-batasan bekerja. Penyebab KPD ialah multifaktor dan biasanya dikaitkan dengan peningkatan stres fisik yang menyebabkan membran ketuban menjadi lemah. ${ }^{5}$

Distribusi kasus KPD terhadap jumlah paritas mendapatkan bahwa kejadian KPD lebih banyak terjadi pada ibu dengan multipara. Hal ini sesuai dengan penelitian yang dilakukan oleh Sumadi dan Ariyani ${ }^{6}$ yang menyatakan bahwa KPD banyak 
terjadi pada multipara. Hal tersebut juga didukung oleh penelitian Nazilla ${ }^{7}$ di RSUP Dr. Hasan Sadikin periode 2013-2015 yang menyatakan bahwa kejadian KPD lebih sering terjadi pada ibu multipara. Kejadian KPD banyak didapatkan pada multiparitas karena kehamilan yang terlalu sering dapat memengaruhi embriogenesis sehingga selaput ketuban yang terbentuk akan lebih tipis dan mudah pecah sebelum waktunya, serta semakin mudah terjadi infeksi amnion karena rusaknya struktur serviks pada persalinan sebelumnya. ${ }^{8,9}$

Pada penelitian ini lamanya KPD terbanyak didapatkan telah berlangsung lebih dari 24 jam, yaitu 51 kasus; 44 kasus di antaranya yaitu ibu dengan usia kehamilan $\geq 37$ minggu (aterm) dan sisanya 7 kasus yaitu ibu dengan usia kehamilan <37 minggu (preterm). Hasil penelitian ini tidak sejalan dengan penelitian Lowing et $\mathrm{al}^{3}$ yang mendapatkan kasus KPD paling banyak berlangsung $<12$ jam yaitu 31 kasus $(52,54 \%)$.

Distribusi kasus KPD terbanyak pada usia kehamilan aterm ( $\geq 37$ minggu) yaitu berjumlah 67 kasus. Hasil ini penelitian ini sejalan dengan penelitian yang dilakukan oleh Lowing et $\mathrm{al}^{3}$ yang mendapatkan hasil terbanyak kasus KPD pada kehamilan aterm, yaitu 50 kasus $(0,69 \%)$. Hasil penelitian ini juga sejalan dengan penelitian oleh Wiadnya ${ }^{10}$ di RSUP Sanglah Denpasar yang melaporkan pasien KPD terbanyak berada pada usia kehamilan $\geq 37$ minggu yaitu 160 pasien. Hal ini menunjukkan bahwa semakin tua umur kehamilan akan mengakibatkan pembukaan serviks dan peregangan selaput ketuban yang memengaruhi selaput ketuban menjadi semakin lemah dan mudah pecah. ${ }^{11}$

Pada penelitian ini distribusi kasus KPD terbanyak pada jenis persalinan seksio sesarea yaitu 67 kasus. Hasil penelitian ini selaras dengan penelitian yang dilakukan oleh Endang et $\mathrm{al}^{12}$ di Rumah Sakit Panti Wilasa Citarum Semarang yang mendapatkan bahwa ibu bersalin dengan KPD sebagian besar diakhiri kehamilannya dengan seksio sesarea yaitu sebanyak 86 kasus $(66,7 \%)$. Hal ini sesuai dengan teori bahwa ibu dengan KPD dapat bersalin secara spontan maupun dengan tindakan atau seksio sesarea. ${ }^{9,13}$ Terjadinya KPD pada persalinan prematur dihubungkan dengan berat badan janin yang kecil. Semakin kecil berat badan janin, semakin besar kemungkinan morbiditas dan mortalitas sehingga tindakan terminasi memerlukan pertimbangan keluarga. Presentasi janin seperti letak lintang atau bokong dan gawat janin juga merupakan penunjuk untuk melakukan terminasi kehamilan. ${ }^{12,14}$

Apgar score terbanyak didapatkan pada bayi dengan ibu yang mengalami KPD yaitu nilai 7-10 $(79,48 \%)$. Hal ini sesuai dengan penelitian yang dilakukan oleh Setiyana ${ }^{15} \mathrm{di}$ BRSD Cepuyang yang melaporkan bahwa ibu yang mengalami KPD kebanyakan melahirkan bayi dengan nilai Apgar baik yaitu sebanyak 36 bayi $(62,07 \%)$. Apgar score baik berarti nilai Apgar $\geq 7$.

\section{SIMPULAN}

Kejadian ketuban pecah dini (KPD) di RSUP Prof. Dr. R. D. Kandou Manado periode 1 Januari-31 Desember 2018 paling sering didapatkan pada usia ibu 20-34 tahun, pendidikan SMA, IRT, multipara, ketuban pecah $\geq 24$ jam, usia kehamilan $\geq 37$ minggu, persalinan seksio sesarea, dan luaran perinatal Apgar score 7-10.

Bagi peneliti selanjutnya diharapkan dapat mengembangkan penelitian ini dengan menggali faktor-faktor lain yang berhubungan dengan ketuban pecah dini. Bagi rumah sakit diharapkan Bagian Rekam Medik agar bisa menampilkan seluruh data pasien khususnya catatan medik lengkap pasien ketuban pecah dini karena hal ini sangat menunjang dalam mendapatkan hasil penelitian yang akurat.

\section{Konflik Kepentingan}

Penulis menyatakan tidak terdapat konflik kepentingan dalam studi ini.

\section{DAFTAR PUSTAKA}

1. Sualman K. Penatalaksanaan ketuban pecah dini. [online] 2009. [cited 2019 Aug 21]. 2019. Available from http://www. medicalstore.com 
2. Kementerian Kesehatan Republik Indonesia. Profil Kesehatan Indonesia Tahun 2017. Jakarta: Kementerian Kesehatan Republik Indonesia; 2018.

3. Lowing J, Lengkong $\mathrm{R}$, Mewengkang $\mathrm{M}$. Gambaran ketuban pecah dini di RSUP Prof. Dr. R. D. Kandou Manado. eCliniC. 2015;3(3):741-4.

4. Emechebe CI, Njoku CO, Anachuna K, Udofia $\mathrm{U}$. Determinants and complications of pre-labour rupture of membranes (PROM) at the University of Calabar Teaching Hospital (UCTH), Calabar, Nigeria. Scholars Journal of Applied Medical Sciences (SJAMS). 2015; 3(5B):1912-7.

5. Tjahjani E. Gambaran umur, paritas, pendidikan dan pekerjaan ibu bersalin terhadap kejadian ketuban pecah dini (KPD) [Skripsi]. Surabaya: Akademi Kebidanan Griya Husada; 2015.

6. Sumadi N, Ariyani A. faktor risiko yang berhubungan dengan kejadian ketuban pecah dini. J Ilm Kebidanan. 2013;1(1).

7. Abrar NM. 2017. Karakteristik luaran kehamilan dengan ketuban pecah dini di RSUP Dr. Hasan Sadikin periode tahun 2013-2015. [cited 2019 Dec02]. Available from http://jurnal.unpad. ac.id/jsk_ikm/article/download/12499/5 692.

8. Manuaba IBG. Ilmu Kebidanan, Penyakit Kandungan dan KB. Jakarta: EGC, 2009.

9. Varney H. Buku Ajar Asuhan Kebidanan (4th ed). Jakarta: EGC, 2008.

10. Wiadnya A. 2016. Gambaran ketuban pecah dini di RSUP Sanglah Tahun 2013. [cited 2019 Dec13]. Available at https://ojs.unud.ac.id/index.php/eum/art icle/download/24707/15956/

11. Budi R, Ayu SN. 2017. Studi deskriptif penyebab kejadian ketuban pecah dini ( KPD ) pada ibu bersalin. [cited 2019 Dec03]. Available from https:// ejournal.almaata.ac.id/index.php/JNKI/ article/download/450/420.

12. Endang S, Lisa D. 2010. Gambaran karakteristik ibu bersalin dengan ketuban pecah dini di Rumah Sakit Panti Wilasa Citarum Semarang tahun 2009. [cited 2019 Dec13]. Available from: https://ejurnal.akbidpantiwilasa.ac.id/in dex.php/kebidanan/article/viewFile/3/2.

13. Saifuddin AB. Ketuban pecah dini, ekstraksi vakum. In: Buku Acuan Nasional Pelayanan Kesehatan Maternal dan Neonatal (1st ed). Jakarta: JNPKKRPOGI, 2002; p. 218-20.

14. Varney H, Kriebs JM, Gegor CL. Perawatan prakonsepsi. In: Buku Ajar Asuhan Kebidanan (4th ed). Jakarta: EGC, 2007; p.77-89.

15. Setiyana A. Hubungan antara lama ketuban pecah dini terhadap nilai apgar pada kehamilan aterm di Badan Rumah Sakit Daerah Cepu [Skripsi]. Surakarta (ID): Fakultas Kedokteran Universitas Muhammadiyah Surakarta; 2009. 